\title{
The potentiality of Green IT for sustainability and corporate responsibility
}

\author{
A. Hoeltl ${ }^{1}$, R. Brandtweiner ${ }^{2} \&$ F. Redl ${ }^{3}$ \\ ${ }^{1}$ Department for Management and Economics, \\ Danube University Krems, Austria \\ ${ }^{2}$ Institute of Information Management \& Control, \\ Vienna University of Economics and Business, Austria \\ ${ }^{3}$ University of Applied Sciences bfi Vienna, Austria
}

\begin{abstract}
Our society and economy is not able to imagine life without information and communication technologies (ICT). This also has effects on energy consumption and emissions. However, ICT also helps different technologies to increase energy and resource efficiency. This paper presents the variety of possibilities for the implementation of Green IT, as well as the advantages and disadvantages of each measure. Furthermore, the most important key figures for evaluating the impacts of ICT are discussed. It is shown that ICT has a high potential to force and implement Corporate Social Responsibility (CSR). CSR relevant information can be disseminated around the world by ICT in a very effective way, and in so doing make companies take responsibility for their business. Although ICT is a driver for growth and development, developed countries still benefit most.

Keywords: Green IT, Green by IT, CSR, Green IT key figures, sustainability.
\end{abstract}

\section{Introduction}

Information and communication technology (ICT) or the so-called Green IT may be an essential precondition for the implementation of sustainability and corporate social responsibility in a company's strategy. On the one hand, Green IT includes any effort to reduce harmful environmental impact caused by ICT, this is achieved through energy and resource efficiency built into the design application over the entire life cycle. In the European Union ICT is responsible for about eight per cent of electrical power consumption and two per cent of carbon dioxide [1]. On the 
other hand, the application of ICT can contribute to energy savings for the company, as for example video conferences. In order to achieve energy and resource reduction, the company will decide on the basis of a wide range of business variables which action or combination of actions in the field of ICT should be implemented. Although being closely connected, productivity and efficiency variables highlight different tendencies and objectives. Efficiency variables specialize in keeping costs as low as possible. While productivity variables aim to reduce costs, but additionally seek to generate added value. This paper investigates a feasible contribution of Green IT to the sustainability and the corporate social responsibility of a company and to what extent the key figures, currently in use, are suitable to evaluate the contribution of Green IT measures to the company's sustainability goals.

\section{Information and communication technology}

Today, more and more data and information have to be processed and illustrated in nearly all areas of business. This requires the increasing availability of information technology in different specialised fields. One of the first definitions of information technology was given by Leavitt and Whisler in 1958 [2] in merging three developments which may arise by the application of computers:

- the fast processing of a high data volumne

- the simplified reaching of decisions by statistic and mathematic approaches

- the use of simulations

The approach of ICT has changed significantly in the advancing development. Originally, the main task of ICT was to support business, this changed to a business optimising function. Currently, ICT is in place as part of the business, too [3]. A switch from a simple to a strategic perspective of ICT in a company may need a couple of years and may be costly. The assessment of the ICT application can be simple by cost accounting or strategically in considering additionally non measurable factors. Schultze [4] defines the following challenges in assessing the benefit of IT:

- Distance to the creation of value: There is no direct reference to added value, but the use of ICT comprises different parts of the company.

- Distance to the benefit effect in time and in content: An investment doesn't always cause a direct benefit effect, further investments can be necessary, e.g. to garantuee system stability.

- $\quad$ Operationalisation: As the benefits of ICT are measurable just qualitative and thereby difficult to compare, operationalisation is challenging.

- Communication: Problems in communication between operating department and ICT department can complicate the benefit evaluation.

- Imputation: The imputation of ICT costs to ICT benefits can cause problems, because the costs are accrued in the ICT, but benefits are generated in the operating departments.

- Multifactorial problem: The benefit of ICT isn't generated automatically. ICT depends on an abundance of other factors, e.g. market development or the company's management. 
- $\quad$ Irreversibility: It might be possible that ICT projects with high investment costs, that don't go according to plan could not be stopped.

- Insecurity: The ICT industry shows a high dynamic, hence insecurity may arise.

These problems in assessing the benefit of ICT can partly be solved by using evaluation methods of classical investment. According to Schulze table 1 shows a variety of basic techniques.

Table 1: Evaluation methods of classical investment.

\begin{tabular}{|l|l|}
\hline Methods & Techniques \\
\hline Investment & Comparative Cost Method \\
& Total Cost of Ownership (TCO) \\
& Internal Rate of Return Method \\
& Net Present Value Method \\
& Calculation of Profitability \\
\hline Multilayered evaluation methods & Critical Success Factor \\
& Multilevel Analysis \\
& Portfolio Analysis \\
\hline Integrated evaluation methods & Decision Tree Technique \\
& Balanced Scorecard \\
& Integrated IV-Controlling \\
& Integriertes IV-Controlling Instruments \\
\hline Multidimensional evaluation & Cost-Benefit Analysis \\
methods & Utility Analysis \\
& Checklist \\
\hline
\end{tabular}

Multidimensional approaches have to consider the probability of implemenation in addition to the benefit. Strategic criteria may be included with multilayered approaches. For a good indication of the evaluation key data systems are used [5]. They are called key performance indicators (KPI), if efficiency or effectivity are measured. ICT key figures can be classified according to their task: regulation tasks, tasks supporting decisions, analysis tasks and monitoring tasks [6].

All ICT applications are managed by ICT controlling, which covers the planning process of ICT projects and products, the reporting system and the ICT cost accounting [7]. Corresponding to the requested effect, cost-oriented and performance-oriented controlling can be choosen. The latter means a strong crosslink between ICT and the company's strategy. ICT controlling combines technical and economic aspects and is part of IT governance as well as of controlling. A basic ICT process modell consists of three phases, the strategic planning, the development and the implementation. The main goal of ICT controlling is determined by two core questions: 1) Which future tasks in the field of ICT have to be solved? 2) How will the measures of resolution be organised? ICT governance means the harmonisation of investments for ICT with the priorities of the business process, furthermore the rules about the ICT decision making and about the responsible people for the implementation. 


\section{Green IT}

Green IT measures enable a more sustainable and responsible performance of a company. The field of application lies in operational as well as in strategic measures. Basically, the application of ICT has effect on society and environment. Regarding the latter, five areas can be distinguished [8]:

1) Production: Environmental impacts by the production, on the one hand toxic waste from the chemical production process and on the other hand energy and water consumption.

2) Components: ICT components made out of heavy metals and flame retardants.

3) Operation: Energy consumption by operation and cooling of the ICT infrastructure.

4) Reuse, reutilisation and recycling: Within the European Union only one third of the electronic scrap is collected, so the EU tightened the Directive on waste electrical and electronic equipment.

5) Indirect environmental impacts: These are the improved availability and the faster processing of data.

One of many different definitions of Green IT is given by Molla and Cooper [9]: "Green IT can be considered as a holistic and systematic approach to address the challenges surrounding the IT infrastructure such as data centre energy efficiency; IT's contribution to reducing the environmental impacts of business IT activities (such as through adopting green technologies), IT's support for environmentally sustainable business practices (such as in enabling green supply chain management through carbon foot print monitoring and building tools for energy management options) and IT's role (such as supplanting high $\mathrm{CO}_{2}$ emitting business practices) in the low-carbon economy."

In their view, Green IT includes the four perspectives sourcing, operations, services and end of ICT life management. The sourcing perspective means environmentally preferable ICT purchasing, the operations perspective focuses on reducing greenhouse gas emissions by improving energy efficiency of ICT application, the system perspective implies the possibilities and the challenge of ICT in contributing to an sustainable business on the whole, while the end of ICT life management perspective corresponds to the reusing, recycling and disposing of IT hardware. According to Molla and Cooper five characteristics are crucial for Green IT:

- Green attitude: All employees who are in contact with ICT have to be aware of environmental impacts of ICT applications.

- Green strategy: A Green strategy is necessary for the ICT value added chain, the procurement, the operation, and the waste management.

- Green practice: The green strategy has to be appreciable in the daily practice, too.

- Green technology: The application of environmental efficient ICT infrastructur, which should be measureable, is necessary.

- Green governance: Here the responsibilities, the roles, and the instruments for IT controlling within a Green IT implementation process are defined. 
Table 2 shows ICT controlling tools and their connection with Green IT goals, which enables a transformation of classical ICT controlling into Green IT controlling. According to a survey of the International Performance Research Institute [10], Green IT key figures are rarely used for controlling. But for an adequate controlling of the environmental impacts of a company, an active Green IT controlling is required. Here two approaches can be distinguished as for cost and performance controlling. One approach focuses on the minimisation of environmental impacts, the other on an efficiency or performance increase, both are regulated by Green IT controlling.

Table 2: Selection of Green IT controlling concepts [11].

\begin{tabular}{|c|c|}
\hline Tools & Goals for Green IT \\
\hline IT strategy & $\begin{array}{l}\text { Reduction of energy consumption and } \mathrm{CO}_{2} \text { emissions, } \\
\text { verification of alternatives (e.g. the place of location of the data } \\
\text { center), application of innovativ technologies, installation of } \\
\text { Green data centres }\end{array}$ \\
\hline $\begin{array}{l}\text { Balanced } \\
\text { scorecard }\end{array}$ & $\begin{array}{l}\text { Consideration of energy consumption and } \mathrm{CO}_{2} \text { goals, } \\
\text { measusres, key figures and indicators }\end{array}$ \\
\hline Lean six sigma & Extension to Green Sigma \\
\hline Standardisation & $\begin{array}{l}\text { Reduction of energy consumption by technical standards like } \\
\text { data visualisation, desktop visualisation, video conferences, } \\
\text { energy-saving mode, printer centralisation }\end{array}$ \\
\hline $\begin{array}{l}\text { IT portfolio } \\
\text { management }\end{array}$ & $\begin{array}{l}\text { Criteria extension for the consideration of Green IT relevant } \\
\text { projects, increase of cost and energy consumption tranparency }\end{array}$ \\
\hline $\begin{array}{l}\text { IT cost and } \\
\text { performance } \\
\text { accounting }\end{array}$ & $\begin{array}{l}\text { Identification and calculation of energy costs and } \mathrm{CO}_{2} \\
\text { emissions }\end{array}$ \\
\hline $\begin{array}{l}\text { Business segment } \\
\text { management }\end{array}$ & Audits in relation to the compliance of the Green IT strategy \\
\hline $\begin{array}{l}\text { IT reporting and key } \\
\text { figures }\end{array}$ & Provision, analysis and counter measures \\
\hline $\begin{array}{l}\text { IT project } \\
\text { controlling }\end{array}$ & $\begin{array}{l}\text { Compliance of the energy consumption and } \mathrm{CO}_{2} \text { goals } \\
\text { Information to the project managers and costumers }\end{array}$ \\
\hline $\begin{array}{l}\text { IT process } \\
\text { management }\end{array}$ & $\begin{array}{l}\text { Internal marketing for the Green IT goals, information and } \\
\text { training for employees, adaptation of the procurement process, } \\
\text { return process for old appliances, retraction process for } \\
\text { consumable materials, identification and reduction of energy } \\
\text { consumption in processes, real-time monitoring of the energy } \\
\text { consumption, automated appliances shutdown for disuse }\end{array}$ \\
\hline
\end{tabular}

\section{Green by IT}

Green by IT means a considerate handling of resources by ICT application. The assumption is, that the core business of a company is responsible for its largest environmental impacts, which can be reduced by the application of ICT. Therefore cost reduction, image improvement, and attractiveness for future employees are goals of Green by IT projects [12]. In order to evaluate projects accurately, they 
have to be considered over the complete life cycle of the used components or technique, including the indirect consequences.

All together, the potential of Green by IT is much higher than the potential of classical Green IT projects. The combination of both approaches enables the highest effectiveness. For an integrated ICT approach the following topics are relevant [13]:

- $\quad$ Anchoring of Green IT in the organisation (by an IT agent).

- Communication of Green IT in the organisation (e.g. environmental reports).

- Optimisation of data centres (e.g. server visualisation).

- Optimisation of ICT in the offices (e.g. desktop virtualisation).

- Optimisation of the IT procurement (e.g. considering energy consumption).

- Optimisation of environmental management (definition of environmental goals for ICT).

\section{Green IT key figures}

There are two main application areas for Green IT, IT in the office and IT in the data centre, latest includes corresponding networks, too [14]. By changings of the IT infrastructure, environmental impacts can be influenced. The optimisation of the data centre is mostly in the focus of companies' Green IT. In the office the concentration is on Green by IT projects, which are difficult to be evaluated by key figures. As for Green IT, the optimisation of the data centre is in the focus, hence corresponding key figures are presented in this chapter.

\subsection{Key figures for optimisation}

Productivity and efficiency key figures are strongly connected, but have different tendencies. Efficiency key figures focus on the minimisation of the costs, productivity key figures simultaneously have the goal to generate additional benefit [15]. The following formula helps quantifying energy efficiency:

$$
\text { Energy Efficiency }=\frac{\text { Revenue }}{\text { Energy Consumption }}
$$

The key figure for productivity is calculated in general by the output and input factors, applied on data centres, the following formula results:

$$
\text { Productivity }=\frac{\text { output }}{\text { Input }}=\frac{\text { Useful Information }}{\text { Resources Used }}
$$

\subsection{Key figures for data centres}

There are three main application areas for Green IT in data centres: the optimisation of IT infrastructur, as of the equipment (e.g. energy supply, cooling and ligthing of the building), the use of renewable resources, and the reuse of used resources. Currently the most used key figures for data centres are the Data Centre 
Infrastructure Efficiency (DCiE) Factor and the Power Usage Effectiveness (PUE) Factor [16, 17].

The Data Centre Infrastructure Efficiency value shows the percentage of the IT energy consumption in relation to the entire energy consumption of the data centre:

$$
D C i E=\frac{I T \text { Energy Consumption }}{\text { Total Energy Consumption }}=\frac{1}{\text { PUE }}
$$

The Power Usage Effectiveness (PUE) value shows the ratio of the total energy requirement of the data centre to the energy delivered to the computing equipment. A PUE value of 1.3 is excellent and means that only $30 \%$ of the energy is used inefficiently.

$$
P U E=\frac{\text { Total Facility Energy }}{\text { IT Equipment Energy }}
$$

\subsubsection{Performance measurement of data centres}

For measuring the performance of the data centres, three key figures are relevant, the IT Equipment Efficiency, the IT Equipment Usage, and the Data Center Energy Productivity.

The key figure IT Equipment Efficiency (ITEE) shows the energy efficiency of the total IT components of the data centre and is calculated from the capacity of all IT components in relation to their energy consumption.

$$
\text { ITEE }=\frac{\alpha * \text { Total Server Capacity }+\beta * \text { Total Memory Capacity }+\gamma * \text { Total Network Capacity }}{\text { IT Energy Consumptioin }}
$$

The key figure IT Equipment Usage (ITEU) evaluates the effectiveness of the IT components in service, using the nominal energy consumption.

$$
I T E U=\frac{I T \text { Energy Consumption }}{I T \text { Nominal Energy Consumption }}
$$

Finally the Data Center Energy Productivity (DCeP) shows like the ITEE the productivity of the data centre:

$$
D C e P=\frac{\text { Generated Benefit }}{\text { Corresponding Energy Consumption in the Data Centre }}
$$

\subsubsection{Reused energy of data centres}

There are three key figures for the reused energy of data centres as well, the Energy Refuse Effectiveness, the Carbon Usage Effectiveness, and the On-site Energy Generation Efficiency.

The key figure Energy Refuse Effectiveness (ERE) measures the energy recovery of the data centre, if energy is used for purposes outside of the data centre.

$$
E R E=\frac{\text { Total Energy Consumption-Reused Energy }}{I T \text { Energy Consumption }}
$$


The key figure Carbon Usage Effectiveness (CUE) shows the $\mathrm{CO}_{2} \mathrm{e}$ emissions of the data centre [18].

$$
C U E=\frac{\mathrm{CO}_{2} \text { e Emissions due to Total Energy Consumption }}{\text { IT Energy Consumption }}
$$

The relation between total energy consumption to external procured energy is evaluated by the On-site Energy Generation Efficiency (OGE) key figure, and shows if the company is producing energy itself [19].

$$
O G E=\frac{\text { Total Energy Consumption }}{\text { External Procured Energy }}
$$

\subsubsection{Overall evaluation of data centres}

For the overall evaluation of data centres one key figure is the Datacenter Performance per Energy (DPPE) value, which uses some of the above presented key figures. Green energy means self-produced energy, free from $\mathrm{CO}_{2}$ emissions.

$$
D P P E=\mathrm{ITEU} * \mathrm{ITEE} * \frac{1}{P U E} * \frac{1}{1-G E C}
$$

with

$$
G E C=\frac{\text { Green Energy }}{\text { Total Energy Consumption }}
$$

Additionally there is a number of further key figures for data centres, e.g. the Water Usage Effectiveness (WUE) value, showing the relation between the water consumption and the IT energy consumption.

$$
W U E=\frac{\text { Water Consumption }}{\text { IT Energy Consumption }}
$$

Figure 1 shows the measurement range of the presented key figures. Actually, not all aspects of a data centre regarding the environmental impacts are considered by these key figures, e.g. the number of rooms, or windows, the lighting in context to the cooling. Additionally, environmental impacts by production, transport or by the recycling process related to the data centre are disregarded. Thus, further development of adequate key figures is necessary.

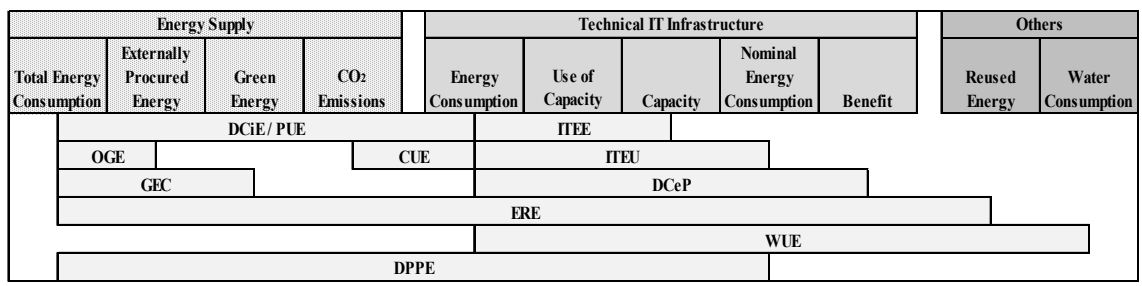

Figure 1: Measurement range of the key figures for data centres according to Baur [20]. 


\section{Application of Green IT}

The application of Green IT is useful in the strategic as well as in the operational area of an organisation. The former itself can be devided in the application of new technologies and the improvement of the building mangement, known as 'Green Building'. Telephone and video conferences are good examples, not only resources and emissions can be reduced and saved, but also time. The intelligent application of ICT systems in buildings can support the efficient resource management in the areas of energy, water and material, additionally structural measures, especially concerning the data centre, enable an optimal waste heat recovery. Operational applications are distinguished for the data centre and the office. For the data center, visualisation is essential for energy optimisation, which means a combination and allocation of resources by ICT for optimising their use of capacity, and causes economical as well as ecological benefits. Applications in the offices are e.g. Thin Clients. In this case the operating system and the user software are located at a central server, therefore harddisks are not necessary in the office. Another example is the optimisation of reinvestments, desktop management, or the paperless office.

\section{$7 \quad$ ICT and Corporate Social Responsibility}

Corporate Social Responsibility (CSR) describes the responsibility of companies for the society, by that for the three pillars of sustainability: environmental, economic, and social. CSR and ICT are linked in manifold ways, e.g. concerning human rights, working time, safety and health issues, physical and psychological pressure, payment issues, serial temporary contracts, environmental footprint, online behavioral advertising, internet and children.

According to $\mathrm{Yi}$ and Thomas [21] environmental impacts of ICT can be categorised to the three-order-effects: first order or direct effects, where the impacts are created by the physical existence of ICT and ICTs processes, second order or indirect effects, creating impacts by the application of ICT, and finally third order means the aggregated, medium and long term effects of the utilisation of ICT around the world. Beside the direct environmental and social effects of ICT, there is a wide range of indirect and third-order effects. The social effects of all three orders of ICT are manifold, like job complexity, monotonous work, skill reproduction, equal treatment for women and minorities, working conditions, health and safety, stress and work pressure, human rights, or the partly irresponsible working conditions (e.g. electronic components production conditions, working conditions in mines, health risk for workers recycling electronic waste) [22].

There are different efforts to force companies taking the responsibility of their business by voluntary initiatives, but also by regulation. The European Union enacted a couple of Directives, Regulations and Communications for reaching the potentials of ICT for making a significant contribution to a sustainable society and therefore for shaping CSR, for example the Directive 2006/32/EC on energy enduse efficiency and energy services, the Directive 2002/96/EC on waste electrical 
and electronic equipment (WEEE), the Directive 2009/125/EC establishing a framework for the setting of ecodesign requirements for energy-related products or the Commission Regulation (EU) No. 801/2013 on ecodesign requirements [23]. The UN Global Compact is a strategic plattform for businesses committing to ten accepted principles in the areas of human rights, labour, environment and anti-corruption. Especially principle 9, "Businesses should encourage the development and diffusion of environmentally friendly technologies", refers among others to ICT [24]. Green IT as well as Green by IT contribute significantly to this principle, regarding the efficient use of energy, water and material, optimising organisational and managerial procedures, and monitoring technologies.

CSR has become a crucial topic for ICT companies in recent years. They are more and more aware of their negative and positive impacts on customers, employees, their entire supply chain, the environment and society. ICT is an important instrument for transparency, it can be used to facilitate the implementation of CSR [25]. ICT offers a wide range of new potentials for innovation within a company, as well as amongst different organisations, by the increased availability and sharing of information. The transfer of knowledge around the world opens completely new possibilities. ICT enables new (social) networks, and may force the unionisation of workers. Additionally, ICT opens a new world in education, nearly each topic is freely available to the public on internet, people who have access to the internet, have access to education, too. Moreover, ICT has an important effect on the feasibility to develop and to monitor CSR, it is essentially for the implementation and promotion of CSR. The huge impact comes from the global range of influence, which enables among others a new dimension of e-participation around the world. ICT is a very effective instrument to disseminate CSR relevant information around the world, and thereby forces companies to take social and environmental issues more seriously. So ICT is a crucial tool in communicating and implementing CSR., As the use of this technology is expensive and not yet adaquately available in all parts of the world, developed countries benefit most from ICT. Nevertheless, ICT as a major driver for growth and development, may help to modernise developing nations, reducing poverty and to contribute to a fairer world.

\section{Conclusion}

Green IT and Green by IT are partly considered as a fad of the ICT industry, as a marketing strategy or a chance for image improvement. However, the paper shows a multitude of possibilities, how Green IT may contribute to cost optimising, and also cost reduction, to an enhancement of productivity, and to the reduction of negative environmental and social impacts of business. Currently, ICT measures are mainly implemented in the operational area, thus different kind of possibilities exist in this area of business. However, the huge potentials of Green by IT in the strategic area of the companies are not used, yet. The reason is probably that the implementation of Green IT is not part of the business stratetegy, but just forced and administrated by ICT specialists. On the strategic level the potential for 
cost and $\mathrm{CO}_{2}$ reductions is much higher than on the operational level, because savings are than feasible not only directly in the ICT department, but in the entire company. Key figures for the evaluation of Green IT measures are available in the operational area, but rarely in the strategic area. Here a multitude of additional criteria has to be considered.

Green IT has a huge potential to reduce the negative environmental and social impact from business, thereby producing a positive force and resulting in the implementation of CSR. However, research regarding the role of ICT in CSR implementation is just at the beginning, quantitative analysis would be necessary for a better understanding of the impact of ICT in this context [26].

\section{References}

[1] Ruth, S. (2009): Green IT More Than a Three Percent Solution? IEEE Internet Computing 13.4, 74-78.

[2] Leavitt, H., Whisler, T. (1958): Management in the 1980s, Harvard Business Review 6, 41-48.

[3] Gadatsch, A. (2010): Influence of Green IT on IT Management and Controlling, in: Teuteberg, F., Marx Gómez, J.: Corporate Environmental Information Systems: Advancements and Trends, 2010, 155-166, New York, ICI, DOI: 10.4018/978-1-61520-981-1.ch010.

[4] Schultze, U. (2010): Informationstechnologieeinsatz im Supply Chain Management. Eine konzeptionelle und empirische Untersuchung zu Nutzenwirkungen und Nutzenmessung. Weber, J. (Ed.): Schriften des Kühne-Zentrums für Logistikmanagement, Gabler, Wiesbaden.

[5] Gladen, W. (2008): Performance Measurement: Controlling mit Kennzahlen, Gabler, Wiesbaden.

[6] Rudolph, S. (2009): Servicebasierte Planung und Steuerung der ITInfrastruktur im Mittelstand. Gabler, Wiesbaden, 13-62.

[7] Brun, R. (2008): Planen - Messen - Steuern: Die Kernprozesse von ITGovernance und IT-Controlling, IM Information Management \& Consulting 23/2, 60-68.

[8] Kosch, B., Wagner, H. (2010): Alles im grünen Bereich - MIT Green IT zu Energieeffizienz und Nachhaltigkeit, in: Spath, O., Bauer, W., Rief, S. (Hrsg): Green Office. Gabler, Wiesbaden, 205-212.

[9] Molla, A., Cooper, V. (2010): Green IT Readiness: A Framework and Preliminary Proof of Concept, Australasian Journal of Information Systems, Vol 16, No 2, 5-23.

[10] International Performance Research Institute (2011): Grünes Controlling, IPRI Journal, Nr. 13.

[11] Gadatsch, A. (2010): Auswirkungen von Green IT auf das IT-Controlling, in: Keuper, F. et al. (Eds.) Business IT, Gabler, Wiesbaden, 357-373.

[12] Heng, S., Klusmann, B., König, F. (2010): "Green IT - Mehr als eine Modeerscheinung!", Studie von Deutsche Bank Research und Green IT Beratungsbüro BITKOM, Berlin. 
[13] Kolbe, L.M., Schmidt, N., Zarnekow, R., Erek, K. (2009): Studie: Nachhaltigkeit und Green IT in IT Organisationen. Status quo und Handlungsempfehlungen. Technische Universität Berlin, Georg-AugustUniversität Göttingen.

[14] Redl, F. (2013): Green IT - Nachhaltigkeit im IT Management. Master Thesis. Vienna.

[15] Anderson, D., et al. (2008): A Framework for Data Center Energy productivity. White Paper 13. the green grid.

[16] Velte, T., Velte, A., Elsenpeter, R. (2009): Green IT: Reduce Your Information System's Environmental Impact while adding to the Bottom Line. McGraw-Hill, Inc., New York.

[17] Rawson, A., Pfleuger J., Cader T. (2008): Green Grid Data Center Power Efficiency Metric: PUE and DCIE. White Paper 06. the green grid.

[18] Avevedo, D., et al. (2010): Carbon Usage Effectiveness (CUE): A Green Grid Data Center Sustainability Metric. WhITe Paper 32. the green grid.

[19] JEITA (2011): Proposal of OGE, On-Site Generation Efficiency Metric, and ECI, Energy Carbon Intensity Metric. Techn. Ber. Green IT Promotion Council.

[20] Baur, H. (2011): Green IT in der Bundesverwaltung, Master Thesis, Darmstadt.

[21] Yi, L., Thomas, H.R., (2007): Review of research on the environmental impact of e-business and IT, Environment International, Vol. 33, pp. 841849.

[22] Martinuzzi, A., Kudlak, R., Faber, C., Wiman, A. (2011): CSR Activities and Impacts of the IT Sector. RIMAS Working Paper, No.5/2011.

[23] Hoeltl, A., Brandtweiner, R., Fuhrmann, B. (2014): EU legislation advancing IT to green? Environmental Impact II, doi: 10.2495/EID140411.

[24] UN Global Compact Office (2014): United Nations Global Compact. Corporate Sustainability in the World Economy. New York.

[25] Freeman, I., Hasnaoui, A. (2010): Information and Communication Technologies (ICT): A Tool to Implement and Drive Corporate Social Responsibility (CSR), https://hal.archives-ouvertes.fr/hal-00495968.

[26] Mahmood, Z., Amir, A., Javied, S., Zafar, F. (2019): Effectiveness of Corporate Social Responsibility and Information Communication Technology in Organizational Change Management, Global Journal of Management And Business Research, Vol. 13/11. 